\title{
Transmission of an Indonesian Isolate of Tobacco leaf curl virus (Geminivirus) by Bemisia tabaci Genn. (Hemiptera: Aleyrodidae)
}

\author{
Noor Aidawati, Sri Hendrastuti Hidayat*, Rusmilah Suseno and Soemartono Sosromarsono ${ }^{1}$ \\ Department of Plant Pests and Diseases, Lambung Mangkurat University, Jalan Jendral A. Yani km. 36, Banjarbaru 70714, \\ Indonesia \\ 'Department of Plant Pests and Diseases, Bogor Agricultural University, Jalan Kamper Darmaga Campus, Bogor 16680, Indonesia \\ (Received on July 22, 2002)
}

\begin{abstract}
Bemisia tabaci Genn. is an important pest worldwide because of its ability to cause damage by direct feeding and its role as a vector of some viruses including geminiviruses. The first report of Tobacco leaf curl virus (TLCV), a Geminivirus, in Indonesia was in 1932 when the virus was found infecting tobacco plants in Central Java. The characteristic symptoms of TLCV included upward curling of the leaf edge, vein thickening, and sometimes the occurrence of enation on the underside of the leaves. Basic studies were carried out to elucidate the characteristics of TLCV transmission by its vector, $B$. tabaci. A single whitefly was able to transmit the virus and the efficiency of transmission was increased when the number of adult whiteflies was increased up to 20 per plant. Inoculation access period of $1 \mathrm{~h}$ could cause transmission up to $20 \%$ and the optimum inoculation access period was $12 \mathrm{~h}$. Acquisition access period of 30 minutes resulted in $\mathbf{7 0} \%$ transmission while $100 \%$ transmission occurred with a $24-h$ acquisition access period. The virus was proven to be persistently but not transovarially transmitted. Discrete fragments of $1.6 \mathrm{~kb}$ were observed when polymerase chain reaction method was applied to detect the virus in viruliferous nymphs and individual adults of $B$. tabaci, while no bands were obtained from non-viruliferous nymphs and adults.
\end{abstract}

Keywords : Bemisia tabaci, geminivirus, Tobacco leaf curl virus, transmission, vector.

Bemisia tabaci (Genn.) is one of the most economically important pests in many tropical and subtropical regions (Bock, 1982). The pest can cause extensive damage in more than 500 species of crops (Greathead, 1986) through its direct feeding, and its ability to directly transmit viruses, including geminiviruses.

The geminivirus is a group of plant viruses with distinct morphological characters. Its twin isometric particles

\footnotetext{
*Corresponding author.

Phone) $+62-251-629364, \cdots$ FAX) $+62-251-629363$

E-mail) shidayat@ipb.ac.id
}

consist of circular single-stranded DNA genomes (Bock, 1982). The first geminivirus that originated from Indonesia was reported by Thung (1932; cited in Trisusilowati et al., 1990). The virus caused leaf curling in tobacco plants. In 1984, Tobacco leaf curl virus (TLCV) caused serious damage in Bojonegoro, East Java, with up to $30 \%$ disease incidence (Poerbokoesoemo, 1984; cited in Trisusilowati et al., 1990). The symptoms of TLCV infection include leaf curling, vein banding, uneven leaf surface, and rigid leaves. The disease affected yield quality, especially those targeted for cigar wrapping.

Because of the widespread occurrence of TLCV epidemic in most tobacco plantations in Indonesia, knowledge of the mode of transmission of the virus from plant to plant by an insect vector $B$. tabaci is essential. Besides, rapid and specific procedures for virus detection are needed in both $B$. tabaci and plants to provide tools in epidemiological and disease management studies. One method that has become a primary means of virus detection and diagnosis was serological-based technique. This approach has been met with limited success due to the high diversity of geminiviruses and the difficulties in obtaining sufficient antisera. Detection method based on analysis of viral nucleic acid has been widely used for geminiviruses. These include nucleic acid hybridization (Bendahmane et al., 1995; Czosnek et al., 1988; Gilbertson et al., 1991; Hidayat et al., 1993; Polston et al., 1989) and polymerase chain reaction (Chiemsombat et al., 1990; Pacheco et al., 1996; Rojas et al., 1993; Roye et al., 1997; Wyatt and Brown, 1996).

This paper reports the characteristic relationship between an Indonesian isolate of TLCV and its insect vector $B$. tabaci, and the development of a polymerase chain reaction-based technique to detect the virus from its insect vector.

\section{Materials and Methods}

Maintenance of virus source, $B$. tabaci, and the plants. Leaves showing .TLCV symptom were collected from tobacco fields at Arjasa and Tegal Gede villages, Jember, East Java. The virus was 
maintained on tobacco plants (Nicotiana tabacum cv. H382) by insect transmission. Healthy tobacco plants were grown in a whitefly-proof screenhouse. Whitefly (B. tabaci) adults were obtained from broccoli plants in Bogor and identified using the identification key of Martin (1987). The insects were reared on tobacco and broccoli (Brassica oleareceae var. Italica) plants in whitefly-proof cages.

Virus-vector relationship. TLCV transmission experiments with B. tabaci were conducted using cylindrical cages with mesh tops, which were inverted over individual leaves. Bemisia tabaci adults were introduced into the cage through a hole which was sealed afterwards. The insects were given access to TLCV-infected tobacco plants in separate whitefly-proof cages. After acquisition access period, the whiteflies were re-collected individually using an aspirator and transferred to separate cages of healthy tobacco plants for inoculation access periods. After inoculation access period, the whiteflies were removed, and the plants were sprayed with an insecticide and held for symptom development in an insect-proof screen house.

The minimum acquisition access period required for transmission of TLCV was determined by allowing $B$. tabaci adults access to TLCV-infected tobacco plants for $0.5,1,3,6,12$, and $24 \mathrm{~h}$ before transferring them to healthy tobacco plants for a $48-\mathrm{h}$ inoculation access period. Ten $B$. tabaci adults per plant were used for each acquisition access period. Fifteen plants were used for each acquisition access period and the percentage of virus infection was calculated from plants showing TLCV symptoms after 10-25 days.

To determine the minimum inoculation access period, $B$. tabaci adults were given a 24 - $\mathrm{h}$ acquisition access period on TLCVinfected tobacco plants and inoculation access periods of $1,3,6$, 12,18 , and $24 \mathrm{~h}$ on healthy tobacco plants. Ten $B$. tabaci adults per plant were used for each acquisition access period. Fifteen plants were used for each acquisition-access period and the percentage of virus infection was calculated from plants showing TLCV symptoms after 10-25 days.

The effect of vector number on the relative efficiency of virus transmission was determined by allowing $1,3,5,10,15$, and $20 B$. tabaci adults a 48-h inoculation access period on healthy tobacco plants after a $24-\mathrm{h}$ acquisition access period on TLCV-infected tobacco plants. Fifteen plants were used for each treatment.

TLCV acquisition by $B$. tabaci nymphs was determined by collecting $4^{\text {th }}$ instars from TLCV-infected tobacco plants using an insect pin. Nymphs were placed on petri dishes until they complete their development. The adults were then removed and fed on healthy tobacco plants for $24 \mathrm{~h}$.

Serial transmission was conducted to determine persistence of the virus on its insect vector. One $B$. tabaci adult was given a 24-h acquisition access period on TLCV-infected tobacco plants and viruliferous insects were transferred serially every $24 \mathrm{~h}$ to healthy tobacco plants. Serial transmission was conducted until the insects die.

The ability of the virus to be transovarially transmitted was determined by rearing viruliferous ' $B$. tabaci in insect-proof screencages. The insects were allowed to lay eggs on broccoli plants, which are not a host of TLCV, for 7 days before removing them from the cages. The eggs were maintained until they hatched, then the adults were allowed to feed on healthy tobacco plants for $24 \mathrm{~h}$.

Detection of TLCV in $B$. tabaci by polymerase chain reaction. Bemisia tabaci adults and nymphs were collected after a 24-h acquisition access period. Sets of $1,5,10,20,30$, and $50 \mathrm{~B}$. tabaci were subjected to DNA extraction following the method of Goodwin et al. (1994), while DNA extraction from tobacco plants was conducted using the method of Dellaporta (1983). The method of Rojas et al. (1993) was used for amplification of viral DNA from $B$. tabaci extracts by polymerase chain reaction (PCR). Amplified DNA fragments were electrophoresed in $1 \%$ agarose minigels in TBE buffer and detected with UV light after staining in ethidium bromide (Maniatis et al., 1982).

\section{Results}

Acquisition feeding period. After a 30-minute acquisition access period, ten Bemisia tabaci adults were able to cause $70 \%$ transmission of TLCV (Table 1). The transmission rate increased as the acquisition access period was prolonged and reached a maximum at 24-h acquisition access period. The TLCV symptoms were upward curling of the leaves and vein banding with crinkle-like symptom.

Table 1. The effect of various acquisition feeding periods of Bemisia tabaci (10 adults per plant) on transmission and incubation period of TLCV on tobacco plants after a 48-h inoculation feeding period

\begin{tabular}{ccc}
\hline \hline $\begin{array}{c}\text { Acquisition feeding } \\
\text { period } \\
\text { (h) }\end{array}$ & $\begin{array}{c}\text { Number of infected } \\
\text { plants } \\
(\%)\end{array}$ & $\begin{array}{c}\text { Incubation } \\
\text { period } \\
\text { (days) }\end{array}$ \\
\hline 0.5 & 70 & $6-13$ \\
1 & 70 & $8-30$ \\
3 & 90 & $9-30$ \\
6 & 90 & $6-30$ \\
12 & 90 & $6-30$ \\
24 & 100 & $4-13$ \\
\hline
\end{tabular}

Table 2. The effect of various inoculation feeding periods of Bemisia tabaci (10 adults per plant) on transmission and incubation period of TLCV on tobacco plants following a 24-h acquisition feeding period

\begin{tabular}{ccc}
\hline \hline $\begin{array}{c}\text { Acquisition feeding } \\
\text { period } \\
(\mathrm{h})\end{array}$ & $\begin{array}{c}\text { Number of infected } \\
\text { plants } \\
(\%)\end{array}$ & $\begin{array}{c}\text { Incubation } \\
\text { period } \\
\text { (days) }\end{array}$ \\
\hline 1 & 20 & $20-28$ \\
3 & 60 & $9-28$ \\
6 & 80 & $15-24$ \\
12 & 90 & $11-27$ \\
18 & 80 & $13-24$ \\
24 & 90 & $10-24$ \\
\hline
\end{tabular}


Table 3. The effect of number of Bemisia tabaci on transmission and incubation period of TLCV on tobacco plants after a 24-h acquisition feeding period and a 48-h inoculation feeding period

\begin{tabular}{ccc}
\hline $\begin{array}{c}\text { Number of } \\
\text { insects }\end{array}$ & $\begin{array}{c}\text { Number of infected plants } \\
\mathbf{( \% )}\end{array}$ & $\begin{array}{c}\text { Incubation period } \\
\text { (days) }\end{array}$ \\
\hline 1 & 50 & $13-29$ \\
3 & 50 & $13-29$ \\
5 & 70 & $12-29$ \\
10 & 70 & $13-29$ \\
15 & 70 & $12-18$ \\
20 & 100 & $11-16$ \\
\hline
\end{tabular}

Inoculation feeding period. One-hour inoculation access period following a 24-h acquisition access period was sufficient to cause $20 \%$ transmission by $10 \mathrm{~B}$. tabaci adults. The number of infected tobacco was increased as the inoculation access period was prolonged (Table 2).

Effect of the number of $B$. tabaci adults on transmission efficiency. Given a $24-\mathrm{h}$ acquisition access period and a $48-$ $\mathrm{h}$ inoculation access period, a single $B$. tabaci adult was able to cause $50 \%$ transmission. The efficiency of transmission increased as the number of $B$. tabaci adults was increased and reached a maximum (100\% transmission) when $20 \mathrm{~B}$. tabaci adults were used. Incubation period of TLCV on infected tobacco plants tended to be shorter as the number of $B$. tabaci adults was increased (Table 3 ).

Acquisition of TLCV by nymphs. Bemisia tabaci adults

Table 4. Persistence of TLCV on Bemisia tabaci after a 24-h acquisition feeding period and $24-\mathrm{h}$ inoculation feeding period

\begin{tabular}{|c|c|c|c|}
\hline \multirow{2}{*}{$\begin{array}{l}\text { Serial transmission } \\
\text { (days) }\end{array}$} & \multicolumn{3}{|c|}{ B. tabacl } \\
\hline & 1 & 2 & 3 \\
\hline 1 & + & - & + \\
\hline 2 & - & + & - \\
\hline 3 & - & + & + \\
\hline 4 & - & + & - \\
\hline 5 & + & + & - \\
\hline 6 & + & + & + \\
\hline 7 & + & + & + \\
\hline 8 & + & + & - \\
\hline 9 & + & + & + \\
\hline 10 & + & + & + \\
\hline 11 & + & - & - \\
\hline 12 & $\mathrm{D}$ & + & + \\
\hline 13 & & + & + \\
\hline 14 & & + & + \\
\hline 15 & & + & + \\
\hline 16 & & $\mathrm{D}$ & + \\
\hline 17 & & & + \\
\hline 18 & & & $\mathrm{D}$ \\
\hline
\end{tabular}

$\overline{{ }^{a}+=\text { successful transmission; }-=\text { no transmission; } \mathrm{D}=\text { death of insect. }}$

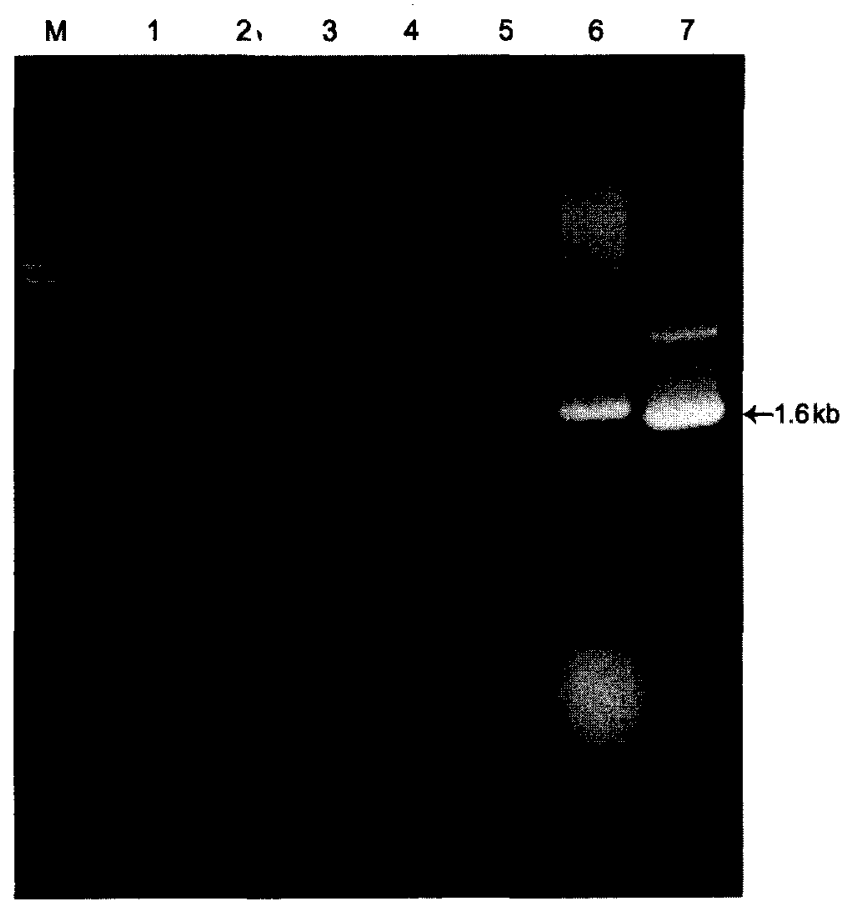

Fig. 1. Polymerase chain reaction-amplified product of TLCV from viruliferous $B$. tabaci. Amplification of $1.6-\mathrm{kb}$ fragments with the primer pair PAL1v 1978 and PAR1c 715 (Rojas et al., 1993). A 10- $\mu$ l aliquot of each polymerase chain reaction mixture was analyzed in a $1.0 \%$ agarose gel. Lane $\mathrm{M}$ is $1-\mathrm{kb}$ ladder size marker. The samples are 1) 1 viruliferous individual of $B$. tabaci with TLCV; 2) 5 individual viruliferous $B$. tabaci with TLCV; 3) 10 individual viruliferous Bemisia tabaci with TLCV; 4) 30 individual viruliferous $B$. tabaci with TLCV; 5) 10 individual non-viruliferous $B$. tabaci; 6) TLCV-infected tobacco; 7) DNA clone of Bean golden mosaic (Geminivirus)-Brazil.

emerging from nymphs that were reared on TLCV-infected tobacco transmitted TLCV after 48-h inoculation access period. All tobacco plants tested showed typical symptoms of TLCV within 8-22 days.

Transovarial transmission of TLCV and persistence of TLCV on B. tabaci. Adult progenies of viruliferous $B$. tabaci were unable to transmit TLCV after they emerged from the eggs. This result proved that TLCV could not be transmitted through eggs.

Serial transmission with a single $B$. tabaci given a $24-\mathrm{h}$ acquisition access period and 24-h transmission interval showed that TLCV was persistent in the insect vector up to the end of their life cycle (Table 4).

Detection of TLCV in B. tabaci by PCR. PCR-amplified fragments of the predicted size from the annealing positions of the primers were obtained from individuals, as well as, from groups $(5,10,30)$ of viruliferous $B$. tabaci (Fig. 1). The same results were obtained when 50 viruliferous nymphs of $B$. tabaci were tested (Fig. 2). PCR-amplified fragments of $-1.6 \mathrm{~kb}$ also showed the concentration of 


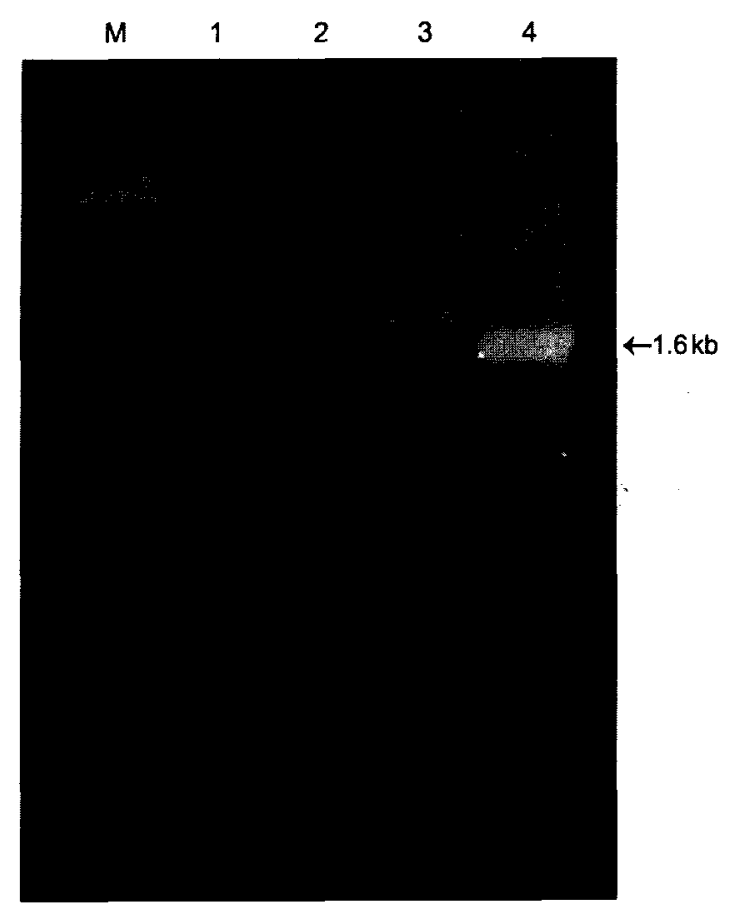

Fig. 2. Polymerase chain reaction-amplified product of TLCV from viruliferous nymphs of Bemisia tabaci. Amplification of 1.6-kb fragments with the primer pair PALlv 1978 and PAR1c 715 (Rojas et al., 1993). A 10- $\mu$ l aliquot of each polymerase chain reaction mixture was analyzed in a $1.0 \%$ agarose gel. Lane $\mathrm{M}$ is $1-$ $\mathrm{kb}$ ladder size marker. The samples are: 1) 50 viruliferous nymphs of $B$. tabaci with TLCV; 2) 20 viruliferous nymphs of $B$. tabaci with TLCV; 3) TLCV-infected tobacco; 4) DNA clone of Bean golden mosaic Geminivirus-Brazil.

TLCV on insect vector. Virus concentrations of 1 and 5 adults, or 10 and 30 adults were not significantly different, but virus concentration of 1 and 5 adults was significantly different from that of 10 and 30 adults. Moreover, concentration of the virus on viruliferous nymphs was much lower than that on the adults.

\section{Discussion}

The probability of subsequent transmission of circulative viruses by insect vectors generally increases with increasing acquisition access period until all insects that are able to do so have acquired the virus (Swenson, 1967). Virus acquisition by insect vectors may depend on the virus titer in the infected plant, the ability of the insect to ingest the virus, and the passage of the virus through the midgut wall and subsequent survival in the insect vector. The higher levels of TLCV transmission efficiency after extended acquisition access in this study are supportive of a circulative mode of transmission.

The ability of insect vector to transmit TLCV is affected by the inoculation access period. Percent transmission increased as the inoculation access period was prolonged (Fig. 2), and reached a maximum (100\%) after a 24-h inoculation access period. Shorter inoculation access period, i.e., $12 \mathrm{~h}$, was achieved with tomato yellow leaf curl virus as reported by Mehta et al. (1994), and with chino del tomate virus (Brown and Nelson 1988).

Transmission of TLCV was observed with one adult $B$. tabaci, but the efficiency of transmission increased almost two-folds as the number of adults was increased to five per plant. Maximum efficiency of $100 \%$ was reached when 20 adults per plant was used in the transmission experiment (Table 3). According to Trisusilowati et al. (1990), five plants showed infection of isolate 2 of TLCV (severe leaf curling and vein banding) and only two plants showed infection of isolate 1 of TLCV (severe leaf curling) when the insects used in the transmission experiment were given acquisition access period on infected tobacco showing mix infection of TLCV isolates 1 and 2. Furthermore, Trisusilowati et al. (1990) reported that one individual insect was unable to transmit isolate 1 . This may suggest the high concentration of TLCV isolate 2 in the infected-tobacco.

The use of PCR technique confirmed the results of the transmission experiment. Viral DNA fragments of expected size of $1.6 \mathrm{~kb}$ was amplified from a single adult of viruliferous $B$. tabaci. As the number of insects was increased, the amount of viral DNA amplified in the polymerase chain reaction became higher, as shown by the brightness of the DNA fragment in the gel electrophoresis (Fig. 1).

Nymphs of $B$. tabaci reared in infected tobacco were viruliferous and the adults that emerged were still viruliferous. TLCV DNA was detected from the nymphs that were reared on TLCV-infected tobacco using PCR technique (Fig. 2). Similar results were shown by Butter and Rataul (1977) with tomato leaf curl virus, as well as, Cohen and Nitzany (1966) and Mehta et al. (1994) with tomato yellow leaf curl virus. Transmission experiment with $B$. tabaci adults emerging from viruliferous nymphs showed that insect molting (nymph-pupa-adult) did not eliminate the virus from the insect body, therefore, the transmission was persistent and transtadial (Table 1). Bos (1983) reported that transmission efficiency is not affected by molting for insect vector transmitting the virus persistently, and virus can be detected in the haemolymph.

TLCV is not transmitted through the eggs. B. tabaci adults emerging from eggs of viruliferous insects were not able to cause infection. The same results were reported by Butter and Rattaul (1977), Mehta et al. (1994), and Idris and Brown (1998) with tomato leaf curl virus, tomato yellow leaf curl virus, and sinaloa tomato leaf curl geminivirus, respectively. Furthermore, Costa (1969) stated that virus transmitted by $B$. tabaci is not transovarial.

As stated by Varma (1963), symptom development of 
TLCV on tobacco plants inoculated serially via viruliferous B. tabaci showed that TLCV persisted in the insect body through the end of the insect's life cycle (Table 1). Persistency of virus in the insect body varies, for example, 1-15 days for tomato yellow leaf curl virus (Cohen and Nitzany, 1966), 8-55 days for tomato leaf curl virus (Butter and Rattaul 1977), 9 days for sinaloa tomato leaf curl geminivirus (Idris and Brown 1998), and the whole life cycle for zinnia yellow net disease (Srivastava et al., 1977).

Detection of TLCV from $B$. tabaci using PCR technique showed that the concentration of the virus increased as the number of insect was increased (Fig. 1). This is in agreement with the experiment on the effect of insect number on TLCV transmission. The more insects inoculated to tobacco plants, the higher the transmission rate and the shorter the incubation period obtained (Table 3). The PCR technique was also able to amplify viral DNA from 50 nymphs of $B$. tabaci after acquisition access period on infected tobacco (Fig. 2). Thus, nymphs of $B$. tabaci could acquire the virus and become viruliferous. The PCR-based detection procedure could be used to detect TLCV from a single insect and groups of nymphs, making it a potential tool for the study of the epidemiological aspect of the disease.

\section{Acknowledgements}

The authors wish to thank Dr. Ir. Endang Budi Trisusilowati, MS (Jember University, East Java Indonesia) for providing assistance in collecting the source of inoculum and for the valuable comments and suggestions; Eliza S. Rusli, Muhammad Taufik, and Syafiari for their technical assistance; and Djoko Prijono for reviewing the paper. The authors are also grateful to the National Research Bureau for the funds made available for this project through the Merit Research Project VI.

\section{References}

Bendahmane, M., Schalk, H. J. and Gronenborn, B. 1995. Identification and characterization of wheat dwarf virus from France using a rapid method for geminivirus DNA preparation. Phytopathology 85:1449-1455.

Bock, K. R. 1982. Geminivirus diseases. Plant Dis. 66:266-270.

Bos, L. 1983. Introduction to Plant Virology. p. 159, Longman Press, New York.

Brown, J. K. and Nelson, R. 1988. Transmission, host range, and virus-vector relationships of Chinol del tomato virus, a whitefly-transmitted geminivirus from Sinaloa, Mexico. Plant Dis. 72:866-869.

Butter, N. S. and Rataul, H. S. 1977. The virus-vector relationship of the tomato leaf curl virus (TLCV) and its vector, Bemisia tabaci Gennadius (Homoptera; Aleyrodidae). Phytoparasit- ica 5:173-186

Chiemsombat, P., Kositratana, W., Attathom, S., Sutabutra, T. and Sae-aung, N. 1990. DNA probe and nucleic acid hybridization for plant virus detection. Kasetsart J. (Nat. Sci. Suppl.) 24:1216.

Cohen, S. and Nitzany, F. E. 1966. Transmission and host range of the tomato yellow leaf curl virus. Phytopathology 56:11271131.

Costa, A. S. 1969. Whiteflies as virus vectors. pp. 95-119. In: Viruses, Vectors, and Vegetation. ed. Marasmorosch, K., p659., John Wiley \& Sons (Interscience), New York.

Czosnek, H., Ber, R., Navol, N., Zamir, D., Antignus, Y. and Cohen, S. 1988. Detection of tomato leaf curl virus in lysates of plants and insects by hybridization with a viral DNA probe. Plant Dis. 72:949-951.

Dellaporta, S. L., Wood, J. and Hicks, J. B. 1983. A plant DNA minipreparation: Version II. Plant Mol. Biol. Rep. 1(4):19-21.

Gilbertson, R. L., Hidayat, S. H. and Martinez, R. T. 1991. Differentiation of bean-infecting geminiviruses by nucleic acid hybridization probes and aspects of bean golden mosaic in Brazil. Plant Dis. 75:336-342.

Goodwin, R. H., Xue, B. G., Kuske, C. R. and Sears, M. K. 1994. Amplification of plasmid DNA to detect plant pathogenic mycoplasmalike organisms. Ann. Appl. Biol. 132:27-36.

Greathead, A. H. 1986. Host plants, pp. 17-25. In: M. J. W. Cock (ed.), Bemisia tabaci A literature Survey on the Cotton Whitefly with an annotated Bibliography. CAB International Institute of Biological Control. Ascot, Berks, U.K.

Hidayat, S. H., Gilbertson, R. L., Hanson, S. F., Morales, F. J., Ahlquist, P., Russel, D. R. and Maxwell, D. P. 1993. Complete nucleotide sequences of the infectious cloned DNAs of bean dwarf mosaic geminivirus. Phytopathology 83:181-187.

Idris, A. M. and Brown, J. K. 1998. Sinaloa tomato leaf curl geminivirus: Biological and molecular evidence for a new subgroup III virus. Phytopathology 88:648-657.

Martin, J. H. 1987. An identification guide to common whitefly pest species of the world (Homoptera: Aleyrodidae). Trop. Pest Manag. 33:298-322.

Mehta, P. J., Wayman, J. A., Nakhla, M. K. and Maxwell, D. P. 1994. Transmission of tomato yellow leaf curl geminivirus by Bemisia tabaci (Homoptera: Aleyrodidae). J. Econ. Entomol. 87:1291-1297.

Pacheco, I. T., Tiznodo, J. A. G., Brown, J. K., Flora, A. B. and Bustamante, R. F. R. 1996. Detection and distribution of geminiviruses in Mexico and the Southern United State. Phytopathology 86:1186-1192.

Polston, J. E., Dodds, J. A. and Perring, T. M. 1989. Nucleic acid probes for detection and strain discrimination of cucurbit geminiviruses. Phytopathology 79:1123-1127.

Rojas, M. R., Gilbertson, R. L., Russell, D. R. and Maxwell, D. P. 1993. Use of degenerate primers in the polymerase chain reaction to detect whitefly-transmitted geminiviruses. Plant Dis. 77:340-347.

Roye, M. E., Mclaughlin, W. A., Nakhla, M. K. and Maxwell, D. P. 1997. Genetic diversity among geminiviruses associated with the weed species Sida spp., Macroptilium lathyroides, 
and Wissadula amplissima from Jamaica. Plant Dis. 81:12511258.

Sambrook, J., Fritsch, E. F. and Maniatis, T. 1989. Molecular cloning. A laboratory manual. 2nd edition. Cold Spring Harbour Laboratory Press, New York.

Srivastava, K. M., Singh, B. P., Dwadash Shreni, V. C. and Srivastava, B. N. 1977. Zinnia yellow net disease-transmission, host range, and agent-vector relationship. Plant Dis. Reptr. 61:550554.

Swenson, K. G. 1967. Plant virus transmission by insect. pp. 267307. In: K. Maramorosch \& H. Koprowski (eds.). Methods in
Virology. Academic Press, New York.

Trisusilowati, E. B., Suseno, R., Sosromarsono, S., Barizi, Soedarmadi and Nur, M. A. 1990. Transmission, serological aspects and morphology of the tobacco krupuk virus. Indon. $J$. Agric. 2:75-79.

Varma, P. M. 1963. Transmission of plant viruses by whiteflies. Nat. Inst. Sci. India Bull. 24:11-33.

Wyatt, S. D. and Brown, J. K. 1996. Detection of subgroup III geminiviruses isolates in leaf extracts by degenerate primer and polymerase chain reaction. Phytopathology 86:12881293. 